\title{
A Global Leadership Model and Its Empirical Applicability
}

\author{
$\mathrm{KISUK}_{\mathrm{CHO}}{ }^{* *} \cdot$ MINAM SOHN ${ }^{* * *}$ AND JISOOK HONG
}

This study attempts to present a global leadership model, which incorporates effective global leadership competencies and makes empirical assessments possible. This global leadership model captures the dynamic interaction of five dimensions of leadership competencies based on common denominators of effective global leadership extracted from former research. The study also explores empirical applicability of the model in Korean companies and the results confirm some assumptions of the model by illustrating that there exists tension between task-orientation and relationship-orientation in the organizations.

Keywords: Global Leadership Model, Self Leadership, TaskOrientation, Relationship-Orientation, Organization, Leadership Competencies, Empirical Assessments

\footnotetext{
The original version of this paper was first presented at the 2002 International Leadership Association in Seattle, Washington, USA, and the updated version with empirical research was presented at the LEADERSHIP FORUM, organized by the China Executive Leadership Academy, Pudong. Shanghai during 19-20 of October 2007. The authors would like to express sincere appreciation to the ILA and CELAP for offering us valuable opportunities, and the two anonymous reviewers for theit helpful comments.

* Professor at the Graduate School of International Studies, Ewha Womans University;

E-mail: choks@ewha.ac.kr

... Former Ph.D. student at the Graduate School of International Studies, Ewha Womans University and current leadership coach

Ph.D. in HRM and former Adjunct Professor in the Business School at Hanyang Univeristy, and current executive director of Den W, women's magazine published in Seoul, Korea
} 


\section{INTRODUCTION}

D

uring the last several decades, leadership studies have focused on the theoretical foundations of leadership within cultural and geographical boundaries, The initial leadership interests started with the inborn characteristics of successful leaders. The inquiry shifted to the effectiveness of leaders' behavior in the context of organizarion. Leaders were classified into the two types: task-oriented versus relationship-oriented. Later attention was given to the interrelationship between leaders and followers and the contingencies in which they interact. Over the last two decades, the focus of debate in leadership studies has been the differences between transactional and transformational leadership. A recent trend of leadership studies is to construct competency models for effective leaders.

Prevailing theories of leadership, unlike general theories in other fields, have limited applications to various regions and cultures. Up until the 1970s, international business was the purview of a relatively small group of business professionals, and hence most leaders considered international business as a sideline rather than the main focus. It was only from the 1980s when the situation started changing dramatically (Morrison 2000). Due to the advent of massive globalization, geographical regions have less meaning for the business community with Samsung opening a plant in England while British Tobacco opened a regional office in Seoul.

The rapid technological development of communication and transportation made the wave of globalization incvitable and irreversible. The necessity for understanding effective global leadership loomed larger than ever before. As business leaders develop keen interests in global leadership, the scholars of the Burns Academy of Leadership have also presented globalization as their platform for $21^{\text {s }}$ century leadership studies (1997). Nonetheless, research on global leadership is still scarce. The leading academic journal in the field, The Leadership Quarterly. has published less than ten articles on global or international issues in the last decade.

The objective of this paper is to identify the competencies of effective global leaders to construct a model of global leadership embracing the existing models and research findings. The word, global has two meanings: one implies a model that can be used in the age of globalization. The other means a more general model that can be applied to various regions and cultures. It aims to develop a succinct model not only encompassing diverse competencies of effective leaders, but also capturing the interactions of various competencies. Further, it examines the applicability of the model employing empirical data analysis.

The next section surveys the existing literature to comprehend research on global leadership. The third section systematically identifies major competencies of effective global leadership and presents a new competency-based model for 
effective global leaders. The fourth section presents the results of empirical analysis using assessment data collected at the workplace. The final section concludes the findings of the study and discusses implications of the major findings and applicability of the model.

\section{GLOBAL LEADERSHIP COMPETENCIES}

Before the turn of the century, leadership scholars had already begun discussing leadership for the $21^{\text {st }}$ century, characterized as an age of globalization and information. Burns (1976) once stated that "a shared, collaborative form of leadership" will be the most successful leadership approach in the next century. He asserts that we need collaborative leadership practices such as fostering human growth and development, facilitating learning, enhancing the quality of life and preservation of nature, creating caring communities of leaders and participants, modeling integrity and authenticity, and demonstrating courage in the future. Allen, Bordas, Hickman, Sorenson and Whitmire (1997) stressed the following principles as key satisfying factors for future collaborative leadership: structuring the learning environment, supporting relationships and interconnectiveness, fostering shared power, practicing stewardship and service, valuing diversity and inclusiveness, and committing to self-development. Futurist Peter Drucker (2002) foresees that leadership of the future will be that of non-profit where the relationship between leaders and followers is based on a certain shared mission pursuing higher ends rather than for-profit in mind.

The wave of globalization has started a new trend in leadership studies. Thus far, there have been mainly two subjects in global leadership research according to a recent review (Morrison 2000). One is "what are the competencies and qualities which make global leaders effective?" The other is "how effective global leaders, who possess competitive competencies and qualities, can be developed?" This study reviews the former literature focusing on the competencies of global leadership to construct an alternative model. Once the model is developed, it will contribute to the second issue, the development of global leadership, as well.

Competency is defined by McBer as a person's underpinning quality which enables an effective set of actions and resulting in the outstanding performance of a job. ${ }^{1}$ Competencies are those factors that distinguish the best from the rest in a given role. They are not the tasks of the jobs, but what enable people to do the tasks. Many studies dealing with managerial competencies tend to use the terminology of competence and competency interchangeably without clear distinction. They can be differentiated as in Table 1 . 
TABle 1. Comparison OF COMPETENCE AND Competency

\begin{tabular}{l|l}
\hline \multicolumn{1}{c|}{ Competence } & \multicolumn{1}{c}{ Competency } \\
\hline What needs to be done in order to perform a job & $\begin{array}{l}\text { Dimensions of behavior lyiug behind competent } \\
\text { performance. } \\
\text { well. }\end{array}$ \\
An area of work. & $\begin{array}{l}\text { The ateributes underpinning a behavior. } \\
\text { Input for desired pertormance/outcome. } \\
\text { Outputs/performance as a result of putsing input } \\
\text { (competency). }\end{array}$ \\
\hline
\end{tabular}

SOURCE: Moote $r t$ al, 2002.

For many global business leaders and leadership scholars, the never-ending question has been 'how can leaders be successful and effective in a severely competitive global market?' If there are indisputable standards or criteria that make leaders effective, leaders can be successful by just following the standards. The answer, however, is not as easy as the question.

According to Morrison (2000), one of the lessons that he had acquired from the study of cross-cultural management literature is that global leadership competency displays critical discrepancy from that of domestic leadership. Norms and basic knowledge of Japan are not applicable to the United States of America. A major reason stems from the uniqueness of global leadership in which culture plays a significant role on norms and values (Morrison, 2000). Therefore, a culture-specific leadership model derived from one region cannot be generalized to other cultures (Morrison, 2000). Numerous studies also noticed the cross-cultural differences in the attitudes, values, and beliefs of leaders (Arvey, Bhagat, and Salas, 1991; Ronen, 1986; Cox, Lobel, and McLeod, 1991) based on studies on Japanese leadership (Misumi, 1985; Graen and Wakabayashi, 1994) as well as on leadership in India (Sinha 1984; Kakar, 1971).

Yeung and Ready (1995) introduced significant differences in the national emphasis on key leadership capabilities in a major study of ten multinational corporations from eight different countries. For example, Korean and German leaders placed a high value on integrity and trust while French leaders emphasized the ability to demonstrate skills of managing internal and external networks (Morrison, 2000). Leadership styles vary with cultures because respective cultures put different emphasis on variables such as ethics, hierarchies, and relationships (Hofstede, 1980; House et al., 2004). A few competency models have been suggested to overcome cultural gaps and create best practices in the global age (Morrison, 2000).

Based on methodological differences, studies of global leadership competencies can be classified into two different groups: descriptive and systematic. The examples of descriptive studies are Brake (1997) and Rhinesmith (1996). Brake (1997) called his global leadership model, the "global leadership triad." Three characteristics of global leadership are (1) relationship management, (2) business acumen, and (3) personal effectiveness. Each of these characteristics has five competencies. 
'Relationship management' includes depth of field, entrepreneurial spirit, professional expertise, stakeholder orientation, and total organizational astuteness. Relationship management involves change agentry, community building, conflict management and negotiation, cross-cultural communication, and influence. Personal effectiveness contains accountability, curiosity and learning, improvisation, maturity, and finally thinking ability. When these components are combined, global leaders demonstrate competencies in all fifteen areas and they additionally have strong transformational selves (Brake, 1997).

Rhinesmith (1996) presented a global leadership model combining 24 competencies. He first lays out three distinctive dimensions such as (1) strategy and structure, (2) people, and (3) corporate culture. In each dimension, Rhinesmith identifies two characteristics, two actions, two skills, and two mindsets under their respective dimension.

Systematic studies include Moran and Riesenberger (1994)'s 12 different competencies. These 12 competencies cluster into four categories: attitudes, interaction, cultural understanding, and leadership. Each category contains three competencies-to facilitate organizational change, to boost up employees to show their excellence, and to create learning systems. Black, Morrison and Gregersen (1999) interviewed about 130 human resources executives from 50 multinational corporations and they concluded that about two-thirds of the competencies of effective global leaders are generalizable while the other third are idiosyncratic. Black et al. (1999) insisted that every global leader needs a core set of characteristics that could be applicable to all contexts. The authors elaborated on two types of savvy as major competencies: global business savvy and global organizational savvy.

The methodology used for global leadership studies are mostly qualitative. Few studies employed empirical data analysis. Sarros and Santora (2001) surveyed and interviewed 181 executives of the top 500 companies in Australia. Among those, 91 percent were male, over 50 years of age, and the majority of them had worked in their current position for about a year or less. Another empirical work can be found in the study of Kets de Vries and Florent-Treacy (1999). In this book, the success-inducing factors of three contemporary CEOs, all of whom had received considerable fame for being successful and effective leaders, were compared and analyzed. The research subjects were Richard Branson of Virgin, Jack Welch of General Electric, and Percy Barnevik of ABB. They are known to have displayed true common traits of global leadership even if each CEO's company had a different history. The way these CEOs exerted their leadership could be viewed as the new paradigm of global leadership.

The analysis of three successful, contemporary global leaders such as Jack Welch, Percy Barnevik, and Richard Branson suggests that factors such as horizontal and self-managing styles are appropriate for future organizations. It has been stressed that the executives of high performing organizations used a more horizontal, 
not hierarchical leadership, encouraging lateral rather than vertical communication. While command and control leadership style is fading, self-managed teams are rising (Kets de Vries and Florent-Treacy, 1999).

Various scholars have suggested their own respective list of competencies. Nonecheless, we were able to identify common denominators: flat and horizontal relationships replacing hierarchical and command-control relationships in the age of information. Aiso, the common traits of effective leaders in successful organizations were trust, honesty, and credibility (Bass, 1985). Furthermore, in future organizations, effective leaders should pay more attention to interpersonal relationships than task-orientation.

These global leadership studies are not free from shortcomings. For example, Brake (1997) selected the vast majority of his samples from US companies and managers (Morrison, 2000). The model presented by Rhinesmith (1996) is overly complicated. Moran and Riesenberger (1994) displayed a problem of nonexhaustiveness. Four categories are viewed as overlapping and lacking parsimony.

\section{GLOBAL LEADERSHIP MODEL: A MODEL OF BALANCE}

Thus far, we have examined the current research on global leadership and discovered that methodology in global leadership is at an infant stage. The global leadership theory or model is descriptive at best, if not totally atheoretical. Hence, we attempt to present an analytic model of global leadership that embraces the current literature and can be used for guiding future empirical research. We first extracted common denominators of the current models as summarized in Table 2. Furthermore, we included additional competencies that we believe global leaders should possess.

Table 2. A Summary Table of Various Global. Leadership Models

\begin{tabular}{|c|c|c|c|}
\hline & Dimension & $\begin{array}{l}\text { Major Comperencies of } \\
\text { Global Leadership Model }\end{array}$ & Related competencies \\
\hline \multirow[t]{2}{*}{1} & \multirow[t]{2}{*}{ Vision } & Insightfulness & $\begin{array}{l}\text { - Visionary and vision-builder (Mlarquardt) } \\
\text { - Being insightful (Speitzer } t \text { al.) } \\
\text { - Have envisioning capacity (Kets de vries; Mead) } \\
\text { - Embrace global/balanced picture (Rhinesmith) } \\
\text { - Global perspective/Vision and strategy (3M's } \\
\text { competency model) }\end{array}$ \\
\hline & & Intcgrity & $\begin{array}{l}\text { Acting with integrity (Speitzer ot al.) } \\
\text { - Accountability (Brake) } \\
\text { - Global perspective (Conner) } \\
\text { - Ethics and integrity (3M's competency model) }\end{array}$ \\
\hline 2 & $\begin{array}{l}\text { Self- } \\
\text { leadership }\end{array}$ & Creativity and risk-taking & $\begin{array}{l}\text { - Innovator and risk-taker (Marquardt) } \\
\text { " Courage to take a stand/takes risks (Speitzer at al.) } \\
\text { - Curiosity (Brake) }\end{array}$ \\
\hline
\end{tabular}




\begin{tabular}{|c|c|c|c|}
\hline \multirow[t]{3}{*}{2} & \multirow[t]{3}{*}{$\begin{array}{l}\text { Self- } \\
\text { leadership }\end{array}$} & Flexibility and adaptability & $\begin{array}{l}\text { - Being flexible (Speitzer ot al.) } \\
\text { - Being open to criticism (Speitzer of al.) } \\
\text { - Seeks opportunities to learn (Speitzer ot al.) } \\
\text { - Learning (Brake) } \\
\text { - Uses/seeks feedback (Speitzer ot al.) } \\
\text { " Thinking agility(Brake) }\end{array}$ \\
\hline & & $\begin{array}{l}\text { Self-awareness and } \\
\text { self-confidence }\end{array}$ & Self-esteem (Sarros and Santora) \\
\hline & & Sclf-control & $\begin{array}{l}\text { Pussess a "hardiness" characteristic from stress (Kets de } \\
\text { vries; Mead) }\end{array}$ \\
\hline \multirow{4}{*}{3} & \multirow{4}{*}{ Task-oricnted } & Professional knowledge & $\begin{array}{l}\text { Business expertise (Conner) } \\
\text { - Professional expertise (Brake) } \\
\text { - Business knowledge (Speitzer ot al.) } \\
\text { - Knowledgeable (Rhinesmith) } \\
\text { - Intellectual capacity (3M's competency model) }\end{array}$ \\
\hline & & $\begin{array}{l}\text { Strategic Thinking } \\
\text { and decision making }\end{array}$ & $\begin{array}{l}\text { Analytical characteristic (Rhinesmith) } \\
\text { Complexity managing skills (Rhinesmith) } \\
\text { - System thinket (Marquardt) }\end{array}$ \\
\hline & & $\begin{array}{l}\text { Get thungs done and } \\
\text { accomplishment of a task }\end{array}$ & $\begin{array}{l}\text { Being committed to success (Speitzer ot al.) } \\
\text { Drive/balance of action (Rhinesmich) }\end{array}$ \\
\hline & & $\begin{array}{l}\text { Understanding of lia-tech } \\
\text { and digital knowledge }\end{array}$ & $\mathrm{N} / \mathrm{A}$ \\
\hline \multirow{5}{*}{4} & \multirow{5}{*}{$\begin{array}{l}\text { Relarionshyp: } \\
\text { orienred }\end{array}$} & Network buildmg skills & $\begin{array}{l}\text { Relationship management (Brake) } \\
\text { Community buiding (Brake) } \\
\text { Polychronic coordinator (Alaryuarde) } \\
\text { Building alliances (5M's competency moslel) }\end{array}$ \\
\hline & & Communication skills & $\begin{array}{l}\text { Communication skills (Conner) } \\
\text { Communication(Brake). }\end{array}$ \\
\hline & & Negetiatim skills & $\begin{array}{l}\text { Conflict management (Brake) } \\
\text { - Negutiation(Brake) }\end{array}$ \\
\hline & & Emparhy & $\mathrm{N} / \mathrm{A}$ \\
\hline & & Respect of diversity & $\begin{array}{l}\text { Cross-cultural (Brake) } \\
\text { Sensitiveness to cultural differences being culeurally } \\
\text { ulventurous (Speitzer of al.) }\end{array}$ \\
\hline \multirow{5}{*}{5} & \multirow{5}{*}{$\begin{array}{l}\text { Organizational } \\
\text { leadership }\end{array}$} & $\begin{array}{l}\text { Adaptation to the } \\
\text { organization }\end{array}$ & $\begin{array}{l}\text { - Organizational astuteness (Brake) } \\
\text { - Able to build and maintain by himsetf (organizational } \\
\text { network), (Kets de vries; Mead) } \\
\text { - Stakeholder orientation (Brake) } \\
\text { - Costumer orientation (3M's competency model) } \\
\text { - Organizational agility (3M's competency mudel) }\end{array}$ \\
\hline & & $\begin{array}{l}\text { Fairness in promotion and } \\
\text { motivation of followers }\end{array}$ & $\begin{array}{l}\text { - Motivational/inspirational skills (Conner) } \\
\text { Bring out the best in people (Speitzer of at.) } \\
\text { - Developing people/inspiring others (3M's competency } \\
\text { model) }\end{array}$ \\
\hline & & Participative management 1 & Have empowerment ability to others (Kets de vries and Mead) \\
\hline & & Change management & $\begin{array}{l}\text { - Change agentry (Brake) } \\
\text { - Change agent (Marquardt) } \\
\text { - Nurturing innovation (3M's competency model) }\end{array}$ \\
\hline & & Business mind & $\begin{array}{l}\text { - Entreprencurial behavior (Conner) } \\
\text { - Global business savvy (Morrison/Gregersen) } \\
\text { - Global organizational savvy (Morrison/Gregersen) } \\
\text { - Entrepreneurial spirit (Brake) } \\
\text { - Business acumen-depth of field (Brake) } \\
\text { - Business health and results (3M's competency model) }\end{array}$ \\
\hline
\end{tabular}


Table 3. Five attributes for Properly Constructed Classification Schemes

\begin{tabular}{cll}
\hline \multicolumn{2}{c}{ Attributes } & \multicolumn{1}{c}{ Description } \\
\hline I Mutual Exclusivity & $\begin{array}{l}\text { Any one leadership competency should not be assigned to more } \\
\text { than one leadership characteristic }\end{array}$ \\
\hline 2 Internal Homogeneity & $\begin{array}{l}\text { The competencies belonging to a certain specific characteristic } \\
\text { must have higher similarity to each othet than to the competencies } \\
\text { belonging to other characteristics }\end{array}$ \\
\hline $4 \quad$ Collective Exhaustiveness & \begin{tabular}{l} 
The model should include every known leadership characteristic \\
\hline 5
\end{tabular} & $\begin{array}{l}\text { Leadership competencies do not readily move from characteristic } \\
\text { to characteristic }\end{array}$ \\
\hline Characteristics & $\begin{array}{l}\text { Names of characteristics which are given should be highly } \\
\text { descriptive and communicable therefore readers are able to easily } \\
\text { understand their meaning }\end{array}$ \\
\hline
\end{tabular}

SOURCE: Mayr (1981) recited from Morrison 2000.

For a proper construction of a classification scheme, we adopted Mayr (1981)'s five attributes (Table 3) to develop an analytic model, which can be used for both conceptual and empirical studies: mutually exclusive characteristics, internally homogeneous characteristics, collectively exhaustive characteristics, stable characteristics, and relevant naming of characteristics. Applying the classification scheme, our global leadership model, called "a model of balance" is summarized in Figure 1.

Figure 1. A Global. Leadership Model.: A Model. in Balance

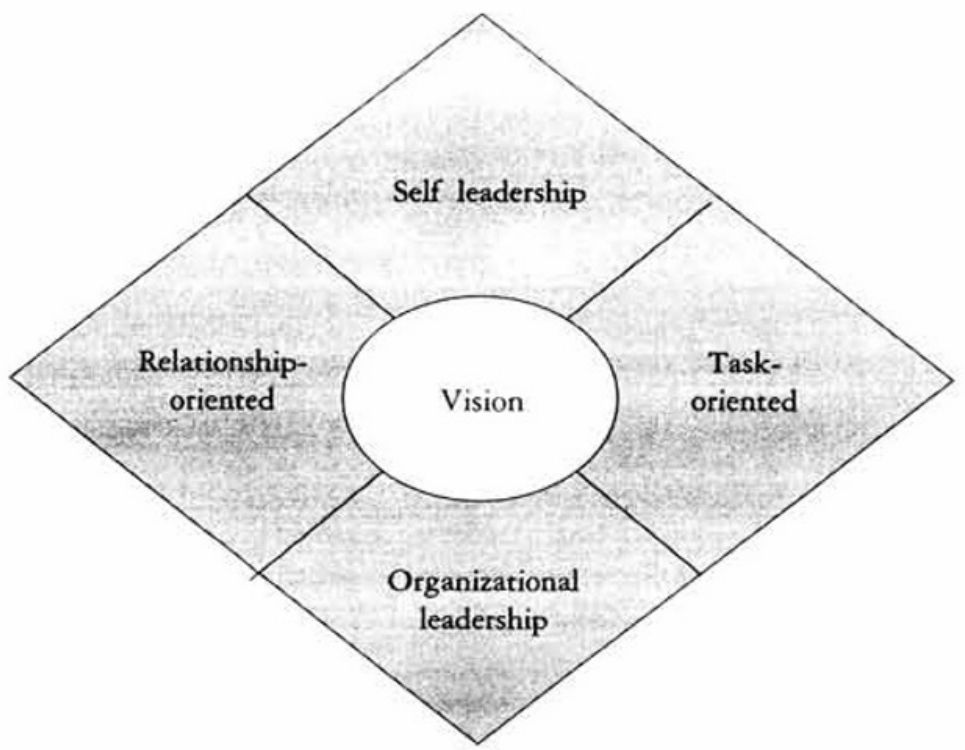


This model has five dimensional leadership categories under which, each respective set of subordinate competencies are as follows in Table 4:

\section{Table 4. Five Dimensional. Leadership Categories and Subordinate COMPETENCIES}

\begin{tabular}{|c|c|c|}
\hline & Dimension & Subordinate competencies \\
\hline 1 & Vision & $\begin{array}{l}\text { - insightfulness } \\
\text { - integrity }\end{array}$ \\
\hline 2 & Self leadership & $\begin{array}{l}\text { creativity and risk-taking } \\
\text { flexibility and adaptability } \\
\text { self-awareness and self-confidence } \\
\text { self-control }\end{array}$ \\
\hline 3 & Task-oriented & $\begin{array}{l}\text { professional knowledge } \\
\text { strategic thinking and decision making } \\
\text { gets things done and accomplishes a task } \\
\text { - understanding hi-tech and digital knowledge }\end{array}$ \\
\hline 4 & Relationship-oriented & $\begin{array}{l}\text { network building skills } \\
\text { - communication skills } \\
\text { - negotiation skills } \\
\text { - empathy } \\
\text { - respect of diversity }\end{array}$ \\
\hline 5 & Organizational leadership & $\begin{array}{l}\text { adaptation of the organization } \\
\text { fairness in promotion and motivation of followers } \\
\text { - participative management } \\
\text { - change management } \\
\text { business-minded }\end{array}$ \\
\hline
\end{tabular}

There has been a hot debate on the validity of competency-based leadership models in recent editions of the Leadership Quarterly. The additive nature of the competencies was questioned (Hollenbeck, McCall Jr., and Silzer, 2006). Thus, we attempt to capture the dynamic interactions of each dimension of the models. The model can be visualized as in Figure 1. The model highlights the importance of vision as vision interacts with other dimensions of competencies from the center. With increasing uncertainty and unpredictability of the environment in the $21^{\text {st }}$ century, the role of vision in leadership becomes even more significant. Vision plays a role of guiding and integrating the other competencies of the four different dimensions. Vision includes the component of integrity, which makes a leader integrated with the vision, and insightfulness which makes a leader foresee the future. In the age of globalization and information, a leader is required to be transparent and honest. Unethical practices are no longer tolerated. The second dimension is called self-leadership. As a society becomes more 
transparent, it requires the self-discipline and self-control of its leaders. Leaders cannot hide or deceive their wrong-doings. Thus, self-leadership is placed on the top of the diamond model. The global leadership may be summarized as 修身臂实治國平天下, only a self-disciplined person will rule his/her family and further lead the nation and the world, as in Confucian teaching.

A person with self-leadership will exercise competencies in task-orientation as well as in relationship-orientation. Relationships become increasingly important in the $21^{\text {st }}$ century, particularly as countries become more democratized and individuals' rights and dignity are more respected. The model captures the inertia of effective leadership and task-orientation in the $20^{\text {th }}$ century. Less advanced or developing counties are experiencing fast social changes. Since they are undergoing rapid industrialization, the culture of these countries reflects the mixture of the pre-industrial, industrial, and post-industrial eras. The importance of task-orientation cannot be underestimated in such countries as global organizations are still competing with traditional organizations.

The ultimate success of leadership lies in organizational leadership. Leadership in organizations should accord with organizational culture to be successful (Schein 1985). If one masters both task-orientation and relationship-orientation, one will eventually be qualified to be a successful leader in the organization. The leader, however, should grasp the organizational culture in addition to other leadership competencies to be a master in organizational leadership. The model captures the interdependence of each dimension by placing the related dimension adjacent. It is not surprising that American scholars seldom emphasize the importance of organizational leadership, as the American organizational culture tends to be horizontal and lateral. In developing countries, each organization has its distinctive culture and the impact of organizational culture on leadership is profound. Thus, we cannot simply dismiss the significance of organizational culture even in the global leadership model.

We also notice that the two sets of dimensions are simultaneously complementary while in tension; (1) Task-orientation and relationship-orientation are places on opposite ends, and (2) self-leadership and organizational leadership are also situated in the same condition. A balance is a key factor in our global leadership model. To the extent that one balances two conflicting dimensions, one will be a successful leader without conflicting competencies that are diametrically opposed. To what extent each dimension should be balanced by the opposite dimension is an empirical question.

\section{EMPIRICAL ASSESSMENTS}

Using the global leadership model, we created a 360 degree multi-rater assess- 
ment tool containing 80 survey questions. Data were collected from the assessments conducted among executive and managerial level leaders in private sectors of South Korea using the created kit. Company samples are purposive as they request our research team to assess actual leadership (competencies) and offer development training program. The organizations are one small company (less than 100 employees), 10 medium-sized companies (100-1000 employees) and 2 large corporations such as LG Chemical and SK Telecom. The type of industry is also various including IT, pharmaceutical, service, and heavy chemical companies. Around 1,137 raters (supervisors, direct reports, peers, others, and self-assessment) participated during 2003-2007. Other's evaluations were used for the current analysis excluding data on self-assessment.

The results of the factor analysis produced five factors: relationship-orientation, task-orientation, organizational competencies, digital based knowledge and professional expertise, and balance in life. Variables related with vision and self leadership were scattered to other three dimensions. The results suggest that three dimensions are empirically identified for global leadership competencies: relationship-orientation, task-orientation, and organization leadership. It is quite striking that organizational leadership exists apart from the other two leadership dimensions. "Benchmarks," a leadership assessment tool invented by the Center for Creative Leadership, contains only two dimensions: task and relationship orientation. The present model suggests that separate organizational dimension needs to be incorporated into the global leadership model.

Two competencies that do not belong to the above three dimensions are digital based knowledge and professional expertise, and balance in life. The result implies that these two competencies are not relevant to leadership competencies in Korea yet. We included these two competencies in a normative sense for future leadership. Korea is ranked the highest among OECD countries in terms of having the longest working hours. It still has further to go in requiring leaders to maintain a balance between work and personal life in Korea.

TABle 5. Regression ANalysis of Task-Orientation AND REI_ATIONSHIP-ORIENTATION ON ORGaNizational. LEADERSHIP

\begin{tabular}{ccc}
\hline Independent Variable & Coefficient & Standard Error \\
\hline Task Orientation & $.814^{* * *}$ & .026 \\
\hline Relationship Orientation & $181^{\cdots *}$ & .025 \\
\hline Adjusted R2 & .80 & \\
\hline
\end{tabular}

NOTES: 1) Dependent Variable: Organizational Leadership.

2) $\mathrm{N}=1137 \quad \cdots \quad \mathrm{P}<.001$.

We also conducted regression analysis to examine the impact of relationship-orientation and task-orientation on organizational leadership. The results 
are shown in Table 5. The results imply that task-orientation has far greater importance than relationship-orientation in the organizations of a transforming society like Korea. We are witnessing the residue of leadership features more associated with the $20^{\text {th }}$ century. Nonetheless, it is interesting to note that the two dimensions are closely linked with organization leadership as the present model posits.

Table 6 displays the interaction term of task and relationship. Although the coefficient of interaction term is not statistically significant, its sign is negative implying that the relationship of the two is in tension as the model stipulates. Since task is found to be more predominant than relationship in Korea, the interaction term is not significant. This question needs to be further pursued with future data analyses.

TABle 6. ANAlysis OF THE INTERACTION EFFECT BetWeEN TASK-ORIENTATION AND RELATIONSHIP-ORIENTATION

\begin{tabular}{ccc}
\hline Independent Variable & Coefficient & Standard Error \\
\hline Task Orientation & $885^{* *}$ & .172 \\
\hline Relationship Orientation & 254 & .052 \\
\hline Task*Relationship Orientation & -.020 & .013 \\
\hline Adjusted R2 & 80 & \\
\hline NOTES: 1) Dependent Variable: Organizational Leadership. \\
2) $\mathrm{N}=1137$
\end{tabular}

2) $\mathrm{N}=1137 \quad \mathrm{P}<.001$

Further, the two dimensions are complementary and reinforce organizational leadership as the model presumes. The results in Table 7 demonstrate mean of organizational leadership competencies of four matrix groups. High relationship-oriented and high task-oriented leaders are likely to exert high organizational leadership competencies. Low relationship-oriented and low task-oriented leaders are likely to show low organizational leadership competencies. The results also support the importance of balance between the two dimensions.

\section{TABle 7. ANOVA ANALYSIS OF MATRIX OF TASK-ORIENTATION AND RELATIONSHIP-ORIENTATION}

\begin{tabular}{ccccc}
\hline & N & Mean & Std. Deviation & Sig. \\
\hline Task High Relationship High & 457 & 4.082 & .380 & \\
\cline { 1 - 3 } Task High Relationship Low & 9 & 3.841 & 0.000 \\
\cline { 1 - 3 } Task Low Relationship High & 130 & 3.607 & .156 & \\
\hline Task Low Relationship Low & 452 & 3.383 & .334 \\
\hline F & 350.728 & & \\
\hline
\end{tabular}




\section{CONCLUSION AND DISCUSSION}

So far, we have reviewed the literature on global leadership competency models and trends, and issues of global leadership research. We discovered the paucity of research in global leadership with the literature showing that most studies have focused on more qualitative and normative research, thereby lacking in empirical rescarch. The study extracted common denominators of the former models to construct a new global leadership model. A model of balance, which has a diamond shape, symbolizes interactions of self-leadership and organizational leadership on the one hand, task-orientation and relationship-orientation on the other. The model captures the dynamic interactions of the five leadership dimensions.

Some assumptions of the model have been investigated employing leadership assessment data. Three findings are noteworthy. First, three dimensions of leadership were identified: task-orientation, relationship-orientation, and organizational leadership, suggesting that organizational dimensions should be included in a global leadership model as a separate dimension. Second, task is far more important than relationship in organizational leadership of South Korean companies. Third, task- and relationship-orientation are complementary to each other in enhancing organizational leadership competencies.

We are living in the age of globalization and information, but the empirical results reiterate the images of traditional organizations of South Korea. Nonetheless, the results show a merit of this model, that is, it captures not only competencies of traditional organizations, but also those of global organizations. The model needs to be elaborated further by additional empirical studies.

\section{REFERENCES}

Allen, Kathleen E., Juana Boardas, Gill Robinson Hickman, Larraine R. Matusak, Georgia J. Sorenson, and Kathryn J. Whitemire. 1998. Leadership in the twenty-first Century in Kellogg Leadership Studies: Rethinking Leadership 1994-1997, Michigan: the Burns Academy of Leadership Press.

Arvey, R. D., R. S. Bhagat, and E. Salas. 1991. Cross-cultural and cross-national issues in personnel and human resources management: Where do we go from here? Res. Pers.Hum. Res. Manage. 9: 367-407.

Bass, B. M. 1985. Leadership and Performance Beyond Expectations, New York: Free Press.

Black, J. S., A. J. Morrison, and H. B. Gregersen. 1999. Global Explorers. The Next Generation of Leaders, London: Routledge.

Blake, Robert R., Herbert A. Shepard, and Jane S. Mouton. 1964. Managing Intergroup Conflict in Industry, Houston: Gulf. 
Brake, T. 1997. The Global Leader. Critical Factors for Creating the World Class Organization, Chicago, IL.: Irwin Professional Publishing.

Boyatzis, R. 1982. The Competent Manager-A Model for Effective Performance, New York: John Wiley and Sons.

Burns, James McGregor. 1978. Leadership. New York: Harper and Row.

Conner J. 2000. Developing the Global Leaders of Tomorrow. Human Resource Management 39(2): 147-57.

Corporate Leadership Council. 2000. 3M's Leadership Competency Framework. Retrieved October 20, 2009, from http://capsnet.usc.edu/ProfessionalDevelopment/Support Tools/documents/3MsLeadershipCompetencyFramework.pdf.

Cox, T., S. Lobel, and P. McLeod. 1991. Effects of Ethnic Group Cultural Differences on Cooperative and Competitive Behavior on a Group Task. Academy of Management Journal 34: 827-847.

Davies, Brent and Linda Ellison. ed. 1997. School Leadership for the 21st Century: a Competency and Knowledge Approach. London. New York: Routledge,

Druker, Peter. 2002. Managing in the Next Society, New York: Truman Talley Books.

Fiedler, F. 1967. A Theory of Leadership Effectiveness, New York: McGraw-Hill.

Graen, G. B. and M. Wakabayashi. 1994. Cross-Cultural Leadership Making: Bridging American and Japanese Diversity for Team Advantage. Handbook of Industrial and Organizational Psychology. $2^{\text {nd }}$ ed. Palo Alto, CA: Consulting Psychologists Press, 4: 415-446.

Gregensen, H. B., A. J. Morrison, and J. S. Black. 1988. Developing Leaders for the Global Frontier. Sloan Management Review 4(1): 21-32.

Hempill, John K. and Alvin E. Coons. 1957. Development of the Leader Behavior Questionnaire. In Leader Behavior: Its Description and Measurement, eds. Ralph M. Stogdill and Alvin E. Coons. Columbus, OH: Ohio State University, Bureau of Business Research.

Hofstede, G. 1980. Culture's Consequences: International Differences in Work-Related Values, Beverly Hills, CA: Sage Publications.

Hollenbeck, George P., Morgan W. McCall Jr., and Robert F. Silzer. 2006.

Leadership competency models. The Leadership Quarterly. 17: 398-413.

Horner, Melissa. 1997. Leadership Theory: past, present and future. Team Performance Management 3(4): 270-287.

House, Robert J., Paul J. Hanges, Mansour Javidan, Peter W. Dorfman, and Vipin Gupta. 2004. Culture, Leadership, and Organizations: The GLOBE Study of 62 Societies. Thousand Oaks, CA: Sage Publications.

House, R. J. and R. R. Mitchell. 1974. Path-goal theory of leadership. Journal of Contemporary Business 3: 81-97.

Kakar, S. 1971. Authority Patterns and Subordinate Behavior in Indian Organizations. Administrative Science Quarterly 16: 298-307.

Kets de Vries M., F. R Manfred, and Elizabeth Florent-Treacy. 1999. The New 
Global Leaders. San Francisco: Jossy-Bass.

Kets de Vries, M. and C. Mead. 1992. The development of the global leader within the multinational corporation. In Globalizing management: Creating and leading the competitive organization. V. Pucik, N. M. Tichy, and C. K. Barnett, eds. Hoboken, NJ: Wiley.

Maczynski, J., A. Jago, G. Rebel, and W. Bohnisch. 1994. Culture and Leadership Styles: A Comparison of Polish, Austrian and U.S. managers. Polish Psychological Bulletin 25(4): 303-315.

Marquardt, Michael J. Nancy O. Berger. 2000. Global leaders for the twenty first century, Albany, New York: State University of New York Press.

Mayr, E. 1981. The growth of biological thought: Diversity, evolution, and inheritance, Cambridge, MA: Harvard University Press.

Misumi, J. 1985. The behavioral science of leadership: An interdisciplinary Japanese research program. Ann Arbor, MI: University of Michigan Press.

Moran, R. T and J. R. Riesenberger. 1994. The Global Challenge Building The New Worldwide Enterprise. London: McGraw-Hill Book Company.

Morrison, A. J. 2000. Developing a Global Leadership Model. Human Resource Management 39(2-3): 117-132.

Moore, D. R., M. Cheng, and A. R. F. Dainty. 2002. Competence, competency and competencies: performance assessment in organizations. Work Study S1(6): 314-319.

Rhinesmith, S. H. 1996. A Manager's Guide to Globalization. Six Skills for Success in a Changing World, New York: McGraw-Hill.

Ronen, Simcha. 1986. Comparative and multinational management. New York: Wiley.

Saal, Frank E. and Patrick A. Knight. 1988. Industrial/Organizational psychology: Science and Practice. Pacific Grove: Brooks/Cole.

Sarros, James C and Joseph C. Santora. 2001. Leaders and values: a cross-cultural study. Leadership and Organization Development Journal 22(5): 243-248.

Schein, Edgar H. 1985. Organizational Culture and Leadership: A Dynamic View, San Francisco, CA: Jossey-Bass.

Sinha, Jai B. P. 1984. A Model of Effective Leadership Styles in India. International Studies of Management \& Organization. Summer/Fall 1984. 14(2-3): 86.

Spreitzer, G. M., McCall, M. W. Jr and Mahoney, J. 1997. The early identification of international executive potential, Journal of Applied Psychology. 82(1): 6-29.

Transformational Leadership Focus Group. 1997. Kellogg Leadership Studies Project: Transformational Leadership Working Papers.

Yeung, A. and D. Ready. 1995. Developing leadership capabilities of global corporations: A comparative study in eight nations. Human Resource Management, Winter, 34(4): $529-547$. 


\section{ENDNOTES} McBer consulting company is an organization which operated for the American Management Association
(Moore $a$ al., 2002). McBer Associates have done studies on personal characteristic approach in managerial
competencies for more than 40 years and, as a result, have offered a definition of competency (Boyatzis
1982). 